\title{
PENGUATAN KEBIJAKAN INVESTASI DAERAH DI KABUPATEN TASIKMALAYA
}

\author{
Iwan Satibi \\ Pascasarjana Universitas Pasundan Bandung \\ Universitas Pasundan Bandung \\ iwan.satibi71@gmail.com
}

\begin{abstract}
Abstrak
Penelitian ini diilhami oleh munculnya fenomena tentang urgensi penguatan kebijakan investasi daerah, khususnya di Kabupaten Tasikmalaya yang hingga saat ini dinilai belum menunjukan perkembangan yang menggembirakan. Padahal, secara fungsional peningkatan investasi daerah diyakini akan memberikan implikasi yang signifikan terhadap akselerasi pembangunan daerah dan kualitas pelayanan publik. Melalui pendekatan kualitatif dan metode deskriptif, penelitian ini telah mengungkap bahwa penguatan kebijakan pengembangan potensi investasi daerah, secara empirik sangat membantu dalam mendukung iklim investasi daerah, baik pada sektor pariwisata, pertanian, kehutanan dan perkebunan, peternakan, perikanan maupun industri. Untuk mendukung keberhasilan kebijakan tersebut, dibutuhkan adanya dukungan dan pelayanan birokrasi, promosi investasi daerah, ketepatan model kemitraan dan kualitas menajamen investasi daerah.
\end{abstract}

Kata Kunci : Kebijakan, Investasi Daerah, Pelayanan Publik

\begin{abstract}
This research was inspired by the emergence of the phenomenon of the urgency of strengthening regional investment policies, particularly in Tasikmalaya Regency, which until now has not been shown to show encouraging developments. In fact, functionally increasing regional investment is believed to have significant implications for the acceleration of regional development and the quality of public services. Through a qualitative approach and descriptive method, this research has revealed that strengthening the policy of developing regional investment potential, empirically is very helpful in supporting the regional investment climate, both in the tourism, agriculture, forestry and plantation, livestock, fishery and industrial sectors. To support the success of the policy, bureaucratic support and services are needed, the promotion of regional investment, the accuracy of the partnership model and the quality of local investment management.
\end{abstract}

Keywords: Policy, Regional Investment, Public Services

Jurnal Academia Praja Volume 3 Nomor 1 - Februari 2020 


\section{PENDAHULUAN}

Secara normatif investasi daerah (local investment) diyakini sebagai suatu kekuatan strategis untuk mengakselerasi pembangunan daerah. Investasi daerah tidak hanya mengembangkan konsep tanpa adanya urgensitas keseriusan pemerintah dalam mereformasi birokrasi. Agenda pemerintah daerah harus jelas dan komprehensif yang diselaraskan dengan iklim investasi. Buruknya iklim investasi saat ini, akibat buruknya kebijakan, salah urus birokrasi dan adanya desentralisasi pemerintahan sebagai konsekuensi logis dari otonomi daerah. Pada sisi lain, munculnya "dis-harmonisasi" kebijakan antara pemerintah pusat dan daerah juga menjadi salah satu kendala yang cukup serius dalam meningkatkan potensi investasi daerah. Sebab itu, perbaikan iklim investasi adalah tantangan bagi pemerintah daerah maupun pusat. Tanpa penguatan kebijakan dan perbaikan kebijakan investasi, niscahya perbaikan perekonomian Indonesia akan segera tercapai. Kondusivitas iklim investasi tersebut perlu dibangun di antaranya, melalui ; 1). Kebijakan Investasi; 2) Dukungan dan Pelayanan Birokrasi Bidang Investasi; 3) Promosi Daerah Dalam Investasi ; 4) Kemitraan (Partnership) Investasi dan (5) Regional Manajemen Investasi.

Persepsi yang dibangun oleh pemerintah daerah atas kepentingan ekonomi daerah tiada lain dengan kelonggaran dan keterbukaan iklim investasi. Betapa pentingnya investasi bagi daerah agar mendorong pertumbuhan ekonomi daerah, langkah yang ditempuh mulai dari promosi investasi, kunjungan pejabat daerah keluar negeri, perumusan kebijakan investasi, penyempurnaan peraturan dan regulasi, penyusunan master-plan investasi, pengembangan sistem informasi investasi, pelayanan one-roof system atau one-stop shop, dan pengembangan partnership. Namu semua itu belum optimal dilakukan dan dikembangkan pemerintah daerah. Ini berarti pemerintah daerah belum sepenuhnya mengalami 
reorientasi peran, dari peran tradisional menuju kewiraswastaan. Di sinilah peran birokrasi sesungguhnya yang harus cerdas dalam menangkap setiap perubahan yang tengah terjadi.

Menurut Budiono (2018) bahwa: Pemerintahan wirausaha bersedia meninggalkan program lama. Ia bersifat inovatif, imajinatif dan kreatif, serta berani mengambil resiko. Ia juga mengubah beberapa fungsi kota menjadi sarana penghasil uang daripada menguras anggaran, menjauhkan diri dari alternatif tradisional yang hanya memberikan sistem penopang hidup. Ia bekerja-sama dengan sektor swasta, menggunakan pengertian bisnis yang mendalam, menswastakan diri, mendirikan berbagai perusahaan yang menghasilkan laba. Ia berorientasi pasar, memusatkan pada ukuran kinerja, memberi penghargaan pada jasa. Ia pun harus mengatakan: "mari kita selesaikan pekerjaan ini dan tidak takut untuk memimpikan hal-hal besar."

Dari ilustrasi di atas akan tumbuh apa yang disebut investasi. Investasi tidak datang sendiri, melainkan harus diundang dengan inovatif, imajinatif dan kreatif, serta berani mengambil resiko. Persis seperti dilontarkan Schumpeter (1994) bahwa investasi otonom (autonomous investment) akan dipengaruhi oleh perkembangan-perkembangan pemerintahan daerah jangka panjang, seperti : 1) Tingkat keuntungan investasi yang diramalkan akan diperoleh; 2) Tingkat bunga; 3) Ramalan mengenai keadaan ekonomi di masa depan; 4) Kemajuan teknologi; 5) Tingkat pendapatan nasional dan pemerintahan daerah serta perubahanperubahannya.

Sejalan dengan konteks di atas, , Kabupaten Tasikmalaya memiliki potensi investasi untuk mengembangkan berbagai sektor ekonomi dalam mendukung potensi yang dimiliki. Berbagai potensi pengembangan ekonomi yang terdapat di Kabupaten Tasikmalaya sejauh ini telah berkembang dengan pesat seiring dengan laju perkembangan dan pertumbuhan kota. Potensi kegiatan perekonomian suatu wilayah pada dasarnya merupakan daya tarik bagi penduduk untuk melakukan usaha di berbagai sektor, karena terdapatnya peluang yang cukup besar untuk 
berusaha. Disamping itu potensi perekonomian ini dapat dijadikan sebagai tolak ukur tingkat pertumbuhan dan perkembangan suatu wilayah/kota.

Pada posisi ini, Pemerintah Kabupaten Tasikmalaya terus berupaya mendorong kemajuan kegiatan ekonomi dari berbagai sektor serta melalui serangkaian paket kebijakan yang mengarah pada pertumbuhan ekonomi terutama dalam skala lokal dan regional. Salah satunya dengan memberikan informasi terhadap perkembangan dan peluang investasi yang dapat dikembangkan dan merupakan manifestasi dari penguatan Kebijakan Pembangunan Pemerintah Kabupaten Tasikmalaya.

Sektor pertanian, industri pengolahan, perdagangan, keuangan, property serta jasa-jasa terus dikembangkan sejalan dengan pertumbuhan dan kebutuhan masyarakat. Namun demikian, secara keseluruhan sektor ini perlu di tingkatkan peranannya terutama bagi pengembangan kegiatan lainnya yang lebih aplikatif dan menarik investasi yang berorientasi pada pengembangan skala besar atau modern. Kegiatan Investasi pada seluruh sektor untuk wilayah Kabupaten Tasikmalaya selanjutnya diharapkan dapat menjadi pendorong terjadinya pertumbuhan secara merata pada seluruh sektor, seperti sektor transportasi, industri daerah, perdagangan, jasa dan investasi lainnya, serta saling mendukung keberadaan potensi yang ada di wilayah Kabupaten Tasikmalaya. Aktivitas investasi perdagangan dan investasi bidang lainnya memungkinkan perekonomian menghasilkan output yang signifikan, pemanfaatan sumber daya lokal secara optimal dan terjadinya dinamika dalam proses pertukaran produksi antar daerah maupun lintas sektor.

Upaya memperkuat dan memperluas sektor investasi dalam konteks pembangunan ekonomi memiliki feasibilitas yang tinggi, mengingat potensi yang dimiliki masyarakat, swasta dan pemerintah cukup signifikan. Namun persoalannya, potensi yang tersebar pada berbagai wilayah tersebut belum terencana secara optimal dan kurang terinventarisir dengan baik. Implikasinya, jelas akan mengganggu kelancaran pertumbuhan ekonomi secara signifikan, 
mengingat kegiatan investasi daerah terutama pada sektor riil merupakan salah satu faktor pendorong berkembangnya sektor ekonomi.

Sejalan dengan konteks di atas, peran serta para investor dalam mendukung akselerasi pembangunan ekonomi tidak hanya membutuhkan dukungan terhadap pembinaan usahanya, tetapi juga membutuhkan serangkaian paket kebijakan yang dapat memberikan penguatan terhadap pertumbuhan iklim investasi daerah. Dengan demikian, para investor dan pelaku usaha lainnya mendapatkan kepastian dan gambaran yang komprehensif tentang peluang investasi daerah yang memungkinkan mereka untuk berinvestasi.

Sesuai dengan konteks kajian yang akan dilakukan, maka metode kajian yang akan digunakan adalah Metode Deskriptif Survey. Penggunaan metode desriptif survey didasarkan pada pertimbangan bahwa metode deskriptif digunakan untuk menggambarkan suatu kondisi/gejala, sistem, peristiwa (seseorang, kelompok orang, lembaga/institusi, masyarakat saat ini berdasarkan data dan informasi yang tersedia (Nawawi, 1998). Selain itu, metode ini tidak hanya sebatas menemukan dan mengumpulkan data serta informasi semata, tetapi juga melakukan analisis dan interpretasi terhadap data dan informasi yang telah diperoleh secara komprehensif. Dengan demikian diharapkan dapat memetakan masalah yang akan dikaji, sehingga hasil kajian tersebut akan memberikan makna yang signifikan sesuai dengan sasaran dan out put kajian yang telah ditetapkan.

\section{PEMBAHASAN}

Pembahasan hasil penelitian ini akan diarahkan pada tiga hal pokok, yakni; pertama, potret potensi investasi daerah Kabupaten Tasikmalaya, kedua faktor penguatan kebijakan investasi daerah, dan ketiga, kendala dan strategi untuk mendukung keberhasilan kebijakan investasi daerah. 


\section{A. Potensi Investasi Daerah}

Untuk mendukung pertumbuhan investasi daerah, Kabupaten Tasikmalaya memiliki beberapa potensi sumber daya unggulan yang cukup feasible untuk dikembangkan. Potensi investasi daerah yang dimaksud, antara lain meliputi: potensi investasi Sektor Pariwisata, Sektor Agribisnis, Sektor Industri Kecil dan Menengah Sektor Kelautan, Sektor Kehutanan dan Perkebunan. Sektor-sektor tersebut dalam kerangka kebijakan pembangunan ekonomi Kabupaten Tasikmalaya merupakan core bisnis unggulan dan berpeluang besar dalam mendorong pertumbuhan ekonomi daerah. Hingga saat ini, pemanfaatan sektor-sektor tersebut belum tergali secara maksimal dan memerlukan kehadiran investor dalam pengembangan lebih lanjut.

\section{Potensi Investasi Sektor Pariwisata}

Potensi pariwisata tersebut tersebar di hampir diseluruh pelosok daerah Kabupaten Tasikmalaya, antara lain: Objek wisata alam Gunung Galunggung, Wisata Bahari Pantai Cipatujah, wisata Tirta Cipanas Pamoyanan, Wisata Budaya Kampung Khas Adat Naga dan Wisata Kriya Rajapolah, dll. Pada tahun 2018 jumlah kunjungan wisatawan baik wisatawan nusantara maupun mancanegara sebanyak 1.421 .728 orang.

\section{Potensi Investasi Sektor Pertanian}

Secara umum Kabupaten Tasikmalaya merupakan daerah pertanian yang mempunyai keunggulan komparatif baik sumber daya alam maupun sumber daya manusianya, Kekayaan sumber daya pertanian yang tersedia tersebut belum dimanfaatkan secara optimal. Sebagai daerah pertanian Kabupaten Tasikmalaya memiliki beberapa komoditas pertanian yang menjadi unggulan daerah yang memerlukan pengembangan yang terdiri dari komoditas tanaman pangan, komoditas sayuran dan komoditas buah-buahan.

\section{Potensi Investasi Sektor Kehutanan dan Perkebunan}

Kabupaten Tasikmalaya pada tahun 2018 mempunyai lahan hutan seluas 
\pm 73.095 Ha dan kebun seluas \pm 59.683 Ha. Potensi hutan dan kebun yang ada merupakan peluang usaha yang cukup baik untuk dikembangkan dalam rangka produksi kayu-kayuan maupun hasil perkebunan. Kerjasama pengembangan hutan rakyat maupun perkebunan rakyat sangat dimungkinkan guna meningkatkan kesejahteraan masyarakat khususnya di Kabupaten Tasikmalaya.

\section{Potensi Investasi Sektor Peternakan}

Kabupaten Tasikmalaya memiliki potensi peternakan yang sangat memungkinkan untuk dikembangkan baik untuk memenuhi kebutuhan konsumsi lokal, regional maupun nasional, hal ini ditunjang oleh karakteristik wilayah Kabupaten Tasikmalaya yang sebagian besar mempunyai perbukitan datar yang luas. Komoditas diantaranya adalah Sapi potong, Kerbau, Kambing, Domba, Itik, Ayam dll. Sektor peternakan khususnya ayam ras sangat terbuka untuk dikembangkan karena Kabupaten Tasikmalaya memiliki potensi daya dukung Sumber Daya Agribisnis dan Sumber Daya Manusia untuk pengembangan peternakan ayam ras.

\section{Potensi Investasi Sektor Perikanan dan Kelautan}

Kabupaten Tasikmalaya sejak dahulu dikenal sebagai salah satu sentra budidaya ikan air tawar di Propinsi Jawa Barat. Komoditas yang sangat prospektif untuk dikembangkan meliputi ikan mas, nilem, gurame, nila, udang galah dan udang vaname.

\section{Potensi Investasi Sektor Industri Kecil}

Kabupaten Tasikmalaya sudah sangat dikenal di tingkat regional maupum internasional sebagai produsen produk industry kerajinan yang handal karena masyarakatnya punya kreativitas dan keterampilan dalam mengolah bahan baku menjadi aneka ragam produk kerajinan. Jenis produk yang dihasilkan sangat bervariatif dan memiliki prospek pasar yang cukup baik bahkan beberapa komoditi pada sector ini seperti anyaman mending, bambu, pandan dan border telah memasuki pasar ekspor. 


\section{B. Faktor Pendukung Penguatan Investasi Daerah}

Investasi daerah merupakan pilar bagi daerah dalam rangka mendukung pembangunan daerah. Keberhasilan daerah dalam mendukung pertumbuhan dan perkembangan investasi daerah merupakan salah satu barometer keberhasilan daerah dalam mendukung pembangunan daerah. Dalam konteks ini, terdapat beberapa faktor pendukung dalam meningkatkan investasi daerah, baik dalam sektor pariwisata, sektor perkebunan dan kehutanan, sektor pertanian, sektor perikanan dan kelautan, serta sektor industri maupun sektor lainnya. Adapun factor pendukung investasi daerah, antara lain; (a) Kebijakan Investasi Daerah, (b) Dukungan dan Pelayanan Birokrasi Bidang Investasi, (c) Promosi Daerah dalam Investasi Daerah, (d) Model Kemitraan dalam Investasi Daerah, (e) Manajemen Investasi Daerah.

\section{Penguatan Kebijakan Investasi Daerah}

Investasi daerah tidak mungkin dapat berkembang dengan baik tanpa adanya serangkaian paket kebijakan yang mendukung pertumbuhan dan perkembangan investasi daerah. Dukungan kebijakan tersebut, dapat dimanifestasikan dalam bentuk kemudahan proses dan prosedur, khususnya terkait dengan perizinan. Dari sisi proses/prosedur perizinan, ditemukan fakta bahwa proses perizinan yang diterapkan di Kabupaten Tasikmalaya saat ini sudah menggunakan model online, sehingga secara operasional tidak banyak menimbulkan permasalahan yang krusial. Fakta ini dikuatkan oleh sejumlah informan yang menyampaikan bahwa proses perizinan di lingkungan Kabupaten Tasikmalaya saat ini, khususnya terkait dengan izin perumahan dan perdagangan dinilai cukup adaptable dan relative berjalan lancar. Namun demikian, untuk perizinan investasi yang berskala besar (secara makro) tampaknya belum banyak yang tertarik, sehingga belum banyak yang masuk. Hal ini disebabkan oleh belum efektifnya desain masterplan yang berkaitan dengan pembuatan klaster industry. Kondisi tersebut kemudian beriplikasi pula pada pengembangan dan pembukaan investasi yang berskala besar. 


\section{Dukungan dan Pelayanan Birokrasi Bidang Investasi}

Investasi daerah juga tidak mungkin dapat berjalan dengan optimal, manakala tidak ada dukungan dan pelayanan birokrasi dalam bidang investasi. Secara empirik dukungan pelayanan dari birokrasi di lingkungan Pemerintah Kabupaten Tasikmalaya selama ini, dinilai sudah cukup baik. Secara kelembagaan, dukungan birokrasi Pemerintah Kabupaten Tasikmalaya diwujudkan dalam bentuk penataan kelembagaaan dan pembentukan Satuan Perangkat Daerah yang secara fungsional dapat membantu dalam mengembangkan investasi di Kabupaten Tasikmalaya. Hal ini tercermin dari pembentukan SKPD yang menangani masalah perizinan, seperti Dinas Penanaman Modal dan PTSP Kabupaten Tasikmalaya.

Secara operasional proses pelayanan perizinan terkait dengan investasi dinilai sudah cukup baik. Dalam konteks tersebut, ada sejumlah prinsip dasar yang menjadi pedoman dalam melayani masalah investasi, sebagaimana dilukiskan oleh Suparno (2017) antara lain; (a) Pelayanan investasi yang efektif, (b) Pelayanan investasi yang efisien, (c) Birokrasi yang professional dalam mengelola investasi, (d) Birokrasi yang proaktif dalam menarik investasi dan (e) Kemampuan Inovasi dalam pelayanan investasi.

Selain itu, birokrasi pelayanan investasi di Kabupaten Tasikmalaya juga telah mengembangkan model pelayanan perizinan yang bersifat transparan dan menekankan adanya kepastian hukum.

\section{Promosi Daerah dalam Investasi Daerah}

Promosi daerah dapat diterjemahkan sebagai proses menginformasikan dan mengingatkan stakeholder akan produk dan potensi daerah kemudian membujuk dan mempengaruhi stakeholder tersebut untuk melakukan pembelian atau berinvestasi. Adapun tujuan dari kegiatan promosi daerah dalam konteks penanaman modal (investasi daerah) anatara lain: (1) Memberikan informasi potensi, peluang, dan prosedur investasi; (2) Meningkatkan realisasi investasi; (3) Membentuk dan mempertahankan citra daerah sebagai daerah yang potensial secara ekonomi, menarik dan nyaman untuk investasi; 
Secara kelembagaan Pemerintah Kabupaten Tasikmalaya sesungguhnya telah melakukan kegiatan promosi daerah untuk tujuan investasi, antara lain dengan melakukan penyediaan dan pelaksanaan promosi melalui media cetak seperti surat kabar, baliho, brosur, dan melalui media elektronik seperti website, media sosial. Namun kegiatan promosi tersebut, diakui belum sepenuhnya efektif dalam mendukung pertumbuhan dan perkembangan investasi daerah Kabupaten Tasikmalaya. Bahkan pada tahun 2018, kegiatan investasi daerah tidak mendapatkan alokasi anggaran untuk melakukan promosi. Minimnya anggaran ini, kemudian berimplikasi pada penawaran investasi di Kabupaten Tasikmalaya. Baru pada tahun 2019, kegiatan investasi daerah Kabupaten Tasikmalaya memperoleh kesempatan untuk melakukan promosi ke tiga daerah, yakni ke Daerah Malang, Yogya dan Solo. Namun demikian, karena terbatasnya anggaran, kegiatan promosi ini juga dirasakan belum sepenuhnya optimal untuk mendukung pengembangan potensi investasi yang ada di Kabupaten Tasikmalaya.

\section{Model Kemitraan dalam Investasi Daerah}

Kemitraan dalam konteks investasi daerah merupakan kontrak di antara para mitra institusi/ perusahaan di mana syarat dan ketentuan kemitraan dinyatakan secara jelas termasuk rasio bagi hasil, kewajiban, aset, investasi, dll. Dengan perkataan lain, Kemitraan pada satu sisi merupakan suatu konsep aliansi strategis bisnis yang dalam implementasinya membutuhkan suatu kesetaraan dan independensi, kompetensi inti (core competance), adanya sesuatu yang dipertukarkan dan risiko serta manfaat (benefit) yang dapat dinikmati bersama.(Hanim \& Ragimun, 2010) Secara kelembagaan model kemitraan yang dibangun oleh Pemerintah Kabupaten Tasikmalaya, diantaranya kerjasama dalam pengelolaan wisata seperti di Wisata Galunggung. Namun demikian, model kemitraan yang melibatkan investasi berskala besar tampaknya belum dirumuskan secara khusus. 


\section{Manajemen Investasi Daerah}

Secara substantive manajemen investasi merupakan suatu manajemen profesional yang memegang berbagai sekuritas atau surat berharga seperti, saham, obligasi serta aset yang lainnya seperti properti bertujuan untuk mencapai target investasi yang dapat menguntungkan untuk investor. Investor tersebut bisa berupa institusi (perusahaan asuransi, perusahaan, dana pensiun dll) atau bisa juga merupakan investor perorangan, dimana sarana yang dipakai umumnya berupa kontrak investasi atau yang biasanya dipakai ialah kontrak investasi kolektif (KIK) seperti redaksana (Maruf, 2012). Dalam konteks tersebut, manajemen investasi daerah Kabupaten Tasikmalaya, tampaknya belum didesain secara komprehensif dan sistematis. Pada posisi ini dibutuhkan langkah strategis untuk mendesain kembali manajemen investasi daerah yang visible sehingga mampu menghadirkan para investor guna mendukung pertumbuhan dan perkembangan investasi di Kabupaten Tasikmalaya. Oleh sebab itu, Pemerintah Kabupaten Tasikmalaya tampaknya harus lebih proaktif dalam melihat kebutuhan investor. Hal ini agar investor bukan hanya sekedar minat, untuk masuk ke Kabupaten Tasikmalaya, tetapi benar-benar melaksanakan pengembangan potensi investasi daerah yang ada di Kabupaten Tasikmalaya secara menyeluruh.

\section{Kendala Pengembangan Investasi Daerah}

Secara empirik, ditemukan beberapa kendala dalam pengembangan dan pertumbuhan investasi daerah di Kabupaten Tasikmalaya. Adapun kendala yang dimaksud, dapat dijelaskan sebagai berikut :

\section{Kendala Pada Sektor Pariwisata}

Pada sektor pariwisata, terdapat beberapa kendala yang dihadapi, antara lain; pertama, Kondisi infrastruktur jalan akses menuju obyek wisata yang rata-rata relative sempit, sehingga secara fungsional kurang menunjang terhadap mobilitas atau transportasi menuju kawasan wisata. Kedua, lemahnya dukungan masyarakat. Sejauh ini terjadi dualisme mindset masyarakat sekitar lokasi obyek wisata, terutama untuk investasi yang bersentuhan dengan fasilitas perhotelan. Kultur 
masyarakat yang memegang teguh nilai-nilai religius islami, menyimpan kekhawatiran terhadap kehadiran hotel atau penginapan di wilayah destinasi wisata akan mengundang praktek-praktek asusila atau prostitusi. Ketiga, belum terintegrasinya aspek pengelolaan destinasi wisata.

\section{Kendala Pada Sektor Pertanian}

Pada sektor pertanian, ditemukan beberapa kendala yang cukup mengganggu pertumbuhan dan perkembangan investasi pada sektor tersebut. Adapun kendala yang dimaksud, antara lain: pertama, status, luas kepemilikan dan alih fungsi lahan yang tidak terkendali. Kedua, ketersediaan infrastruktur (prasarana dan sarana pertanian) dinilai belum memadai yang diakibatkan oleh faktor masih rendahnya kesadaran masyarakat untuk memelihara infrastruktur dan sarana prasarana. Ketiga, rendahnya kualitas dan kuantitas sumberdaya manusia pertanian dan kelembagaan pertanian. Keempat, keterbatasan akses petani terhadap lembaga permodalan. Kelima, belum optimalnya koordinasi instansi terkait dalam menunjang pembangunan sektor pertanian. Keenam, Dampak Perubahan Iklim (DPI). Ketujuh, masih rendahnya daya saing kompetitif dan komparatif. Kedelapan, masih tingginya penggunaan pupuk dan pestisida dan organik. Kesembilan, masih lemahnya mentalitas para petani. (Ismail, 2014)

\section{Kendala Pada Sektor Kehutanan}

Pada sektor kehutanan, ditemukan adanya beberapa kendala yang cukup mengganggu terhadap pertumbuhan dan perkembangan investasi dari sektor tersebut. Adapun kendala yang dimaksud, antara lain: pertama, lamanya proses pengajuan permohonan HGU (Hak Guna Usaha). Kedua, Perda Agribisnis yang kurang mendukung. Ketiga, belum efektifnya koordinasi lintas sektoral. Keempat, kondisi infrastruktur yang kurang mendukung. Akses jalan menuju perkebunan di Kabupaten Tasikmalaya mayoritas dalam keadaan rusak, meski sebagian kecil dalam kondisi baik. 


\section{Kendala Pada Sektor Perikanan}

Pada sector perikanan, ditemukan adanya sejumlah kendala yang menghambat pertumbuhan dan perkembangan investasi pada sektor ini. Adapun kendala yang dimaksud, antara lain dapat dijelaskan sebagai berikut: pertama, terbatasnya ketersediaan lahan. Keberadaan lahan atau kolam dengan lokasi yang strategis atau di jalur sumber air sangat terbatas. Kedua, adanya pencemaran air. Penggunaan bahan pestisida atau bahan kimia dalam kegiatan pertanian telah mencemari air di kawasan sentra budidaya perikanan. Ketiga, Manajemen tradisional yang masih diterapkan petani budidaya ikan di Kabupaten Tasikmalaya dalam menjalankan usahanya, diyakini menjadi hambatan investor yang hendak melakukan investasi dengan pola kerjasama. Keempat, fluktuasi harga pakan. Harga pakan ikan yang tidak stabil karena dipengaruhi nilai tukar rupiah terhap dollar Amerika menjadi tantangan dalam sektor usaha ini.

\section{Kendala Pada Sektor Industri}

Pada sektor industri, ditemukan adanya sejumlah kendala. Adapun kendala investasi dari sektor Industri, dapat dijelaskan sebagai berikut: pertama, masih terbatasnya strategi pemasaran dan akses pasar yang belum jelas mengakibatkan pasar industri kerajinan saat ini hanya berorientasi untuk memenuhi pasar domestik. Kedua, masih lemahnya kualitas sumber daya manusia. Ketiga, terbatasnya akses pembiayaan, karena keterbatas kemampuan untuk menyusun laporan keuangan membuat para pelaku usaha belum memiliki kriteria yang mendukung pihak penyedia modal untuk memberikan bantuan modal.

\section{Strategi Untuk Mendukung Kebijakan Investasi Derah}

Mencermati berbagai tantangan, kendala serta peluang yang dihadapi oleh Pemerintah Kabupaten Tasikmalaya dalam konteks pengembangan potensi investasi daerah, maka dibutuhkan adanya strategi guna mendukung keberhasilan kebijakan investasi daerah. Adapun strategi yang dimaksud, antara lain:

1. Dibutuhkan adanya desain kebijakan yang mampu mendukung pengembangan iklim investasi daerah yang lebih feasible (Sopandi \& Nazmulmunir, 2012). 
Misalnya, penyusunan kebijakan grand design (Masterplan) Pembuatan Rencana Umum Penanaman Modal (RUPM). Dengan demikian, Pemerintah Kabupaten Tasikmalaya memiliki dokumen rencana strategis untuk jangka panjang dalam mengkonsolidasikan semua potensi investasi daerah dalam rangka pembangunan daerah.

2. Dibutuhkan adanya masterplan pariwisata yang dijustifikasi melalui peraturan daerah atau peraturan bupati. Hal ini sangat penting untuk dilakukan untuk memberikan penguatan terhadap arah pembangunan pariwisata di Kabupaten Tasikmalaya.

3. Dibutuhkan adanya kegiatan (program) promosi penanaman modal, dimana Dinas Komunikasi dan Informatika Kabupaten Tasikmalaya dapat menjadi leading sector untuk kegiatan ini. Adapun kegiatan yang dilakukan meliputi langkah-langkah sebagai berikut: (a) Melakukan identifikasi dan pemetaan potensi investasi daerah secara komprehensif dan sustainable, (b) Membangun citra (image) daerah sebagai tempat yang ramah dan kondusif terhadap dunia usaha; (c) Mendesain strategi promosi yang adaptif, inovatif dan tepat sasaran; (d) Melaksanakan berbagai jenis kegiatan promosi yang lebih proaktif dan inovatif untuk meningkatkan investasi seperti pameran, forum, kunjungan, talk show, seminar, business matching, roadshow, iklan; (e) Penyediaan dan pelaksanaan promosi melalui media cetak seperti surat kabar, majalah, baliho, brosur, dan melalui media elektronik seperti website, media sosial, videotron, radio, dan televisi;

4. Perlu dilakukan colaborative governance yang melibatkan semua pemangku kepentingan. Dengan demikian, diharapkan dapat terbangun model kemitraan yang lebih sinergis, antara Pemerintah Kabupaten Tasikmalaya dengan semua stakeholders. Leading sector kegiatan ini, bisa diinisiasi oleh DPMPTSP Kabupaten Tasikmaya.

5. Dibutuhkan adanya penataan dan revitalisasi infrastruktur, khususnya jalan yang menuju berbagai destinasi wisata di Kabupaten Tasikmalaya. Dengan 
demikian, diharapkan dapat mempermudah aksesibilitas, sehingga lebih menarik wisatawan untuk berkunjung keberbagai destinasi wisata. Leading sector kegiatan ini dilakukan oleh Dinas Pekerjaan Umum, Tata Ruang, Perumahan dan Pemukiman Kabupaten Tasikmalaya.

6. Dalam rangka membangun persamaan persepsi, antara masyarakat (tokoh masyarakat) dengan para pengusaha, khususnya yang bergerak dalam perhotelan, dibutuhkan adanya pola komunikasi yang di inisiasi oleh Pemerintah Kabupaten Tasikmalaya dalam rangka mengeleminir terjadinya dualisme mindset masyarakat, sehingga terbangun citra positif dalam pengembangan investasi daerah, khususnya pada sektor wisata. Leading sector untuk kegiatan ini, bisa di inisiasi oleh Dinas Pariwisata bekerjasama dengan Majelis Ulama Kabupaten Tasikmalaya.

7. Untuk lebih meningkatkan kualitas pelayanan perizinan, dalam rangka mendukung potensi investasi daerah, dibutuhkan adanya penerapan konsep benchmarking pada lembaga perizinan. Benchmarking adalah suatu proses yang biasa digunakan dalam manajemen atau umumnya manajemen strategis, dimana suatu unit/bagian/organisasi mengukur dan membandingkan kinerjanya terhadap aktivitas atau kegiatan serupa unit/bagian/organisasi lain yang sejenis baik secara internal maupun eksternal. Leading sector untuk kegiatan ini, adalah DPMPTSP Kabupaten Tasikmalaya.

8. Untuk mendukung pengembangan investasi daerah di Kabupaten Tasikmalaya, para pengusaha, masyarakat dan stakeholders lainnya diharapkan dapat lebih proaktif untuk menanamkan modalnya, sesuai pilihan potensi investasi yang diminati sesuai dengan bidang usaha masih-masing. Pola kerjasama yang dibangun bisa melalui konsep government to private (pemerintah dan swasta), konsep triple helix (pemerintah, bisnis, akademisi), dan bahkan konsep penta helix (pemerintah, pengusaha, masyarakat, akademisi, dan media). 


\section{KESIMPULAN}

Berdasarkan interpretasi dan hasil analisis yang telah dilakukan, maka hasil kajian potensi investasi daerah di Kabupaten Tasikmalaya secara komprehensif menyimpulkan hal-hal sebagai berikut:

1. Untuk mendukung pertumbuhan investasi daerah, Kabupaten Tasikmalaya memiliki beberapa potensi sumber daya ekonomi unggulan yang feasible (layak) untuk dikembangkan. Adapun Potensi-potensi tersebut meliputi: Sektor

Pariwisata, Sektor Agribisnis, Sektor Industri Kecil dan Menengah Sektor Kelautan, Sektor Kehutanan dan Perkebunan

2. Dari sekian banyak potensi investasi daerah yang dimiliki oleh Kabupaten Tasikmalaya, potensi pariwisata, khususnya destinasi wisata kawasan gunung galunggung dan wisata pantai, tampaknya memberikan peluang yang relative lebih prospektif. Hal ini didasarkan pada pertimbangan, bahwa sektor pariwisata tampaknya mengalami perkembangan yang cukup signifikan seiring dengan dinamika dan pergeseran perilaku masyarakat yang cenderung membutuhkan aspek rekreatif. Dalam konteks ini, destinasi wisata kawasan gunung galunggung dan kawasan pantai, menawarkan pesona tersendiri bagi Kabupaten Tasikmalaya, sehingga membuka peluang untuk dikembangkan. **

\section{DAFTAR PUSTAKA}

Budiono, 2018, Analisis Investasi dan Pertumbuhan Ekonomi, Yogyakarta, BPFE

Hanim, Anifatul dan Ragimun, "Analisis Factor-faktor yang Mempengaruhi Minat Investasi di Daerah : Study Kasus di Kabupaten Jember Jawa Timur", Majalah Ekonomi dan Keuangan, Vol 14 No 3 Tahun 2010

Maruf, Ahmad, “Strategi Pengembangan Investasi Daerah : Pemberian Insentif Ataukah Kemudahan "?, Jurnal Ekonomi dan Studi Pembangunan, Vol 13, No 1, April 2012 
Ismail, Isa, "Kendala Investasi di Era Otonomi Daerah", Jurnal Politika, Vol. 5 No 1, Oktober 2014

Hadari Nawawi, 2007, Metode Penelitian Bidang Sosial, Yogyakarta: Gajah Mada University Press

Schumpeter, Joseph, 1994, The Theory Of Economic Development, Harvard Economic Studies

Sopandi, Andi dan Nazmulmunir, Nandang, "Pengembangan Iklim Investasi Daerah", Jurnal Kybernan, Vol 3 No 1, Maret 2012

Suparno, "Inovasi Daerah Untuk Meningkatkan Iklim Investasi”, Jurnal Mimbar Administrasi, Vol 1, No 1, Oktober 2017 